\title{
Ator A Zan Adua (Christian Traditional Rulers) and Tiv Culture in the $21^{\text {st }}$ Century
}

\author{
Andrew Philips Adega (Corresponding author) \\ Department of Religion and Cultural Studies, Benue State University \\ Makurdi, Nigeria
}

Tel: 234-805-522-0744; 234-703-128-0203Ｅ-mail: aadega@bsum.edu.ng; andy4everyoung@gmail.com

Daniel Terna Degarr

Department of History, Benue State University

Makurdi, Nigeria

Tel: 234-803-240-1274; 234-803-240-1274Ｅ-mail: ddegarr@bsum.edu.ng; ddegarr@gmail.com

\author{
Myom Terkura \\ Department of History, Benue State University \\ Makurdi, Nigeria \\ Tel: 234-806-811-1655Ｅ-mail: cynthiamyom@yahoo.co.uk \\ Received: July 8, 2021 Accepted: August 7, 2021 Published: August 8, 2021 \\ doi:10.5296/ijch.v8i2.18915 URL: https://doi.org/10.5296/ijch.v8i2.18915
}

\begin{abstract}
The chieftaincy and traditional rulership institution is dynamic and one of the most enduring legacies from traditional African societies. Until the coming of the colonialists, the traditional institution led by chiefs, emirs, obas, Ezes, etc performed legislative and judicial functions as well as political, religious, social and economic roles etc. The chieftaincy and traditional rulership institution among the Tiv was not organised in a systematic manner until the
\end{abstract}


creation of the Tor Tiv stool in 1946. With several reformations, the chieftaincy institution has taken a definite stage in Tiv society. However, the problem of the study has to do with the fact that there has arisen in the Tiv chieftaincy scene; the ator a zan adua (Christian traditional rulers) who rather than protect and preserve Tiv cultural heritage are in the vanguard of the corrosion of a culture they had taken an oath to protect and preserve. If prompt action is not taken by the Tiv, their culture would soon disappear as these ator a zan adua have "churchmentised" and Christianised Tiv culture. As scholars of Tiv History, Religion and Culture, the researchers are alarmed at this cultural imperialism being perpetrated by Tiv traditional rulers. The study adopts the historical, descriptive and evaluative methods. In data collection, the primary and secondary methods have been adopted. In the primary source, oral interviews and the observation methods have been used; whereas in the secondary sources of data collection, documented sources from books, journal articles, newspapers and e-sources have been employed. The study established that by the orientation of ator a zan a dua as Christians, they are on the verge of completely supplanting Tiv culture with a foreign one. The study noted that culture gives an identity to a group of people and without it, they cannot be defined. In view of this challenge, the study made various suggestions as means of preserving and sustaining Tiv cultural heritage for generations yet unborn. One of these suggestions is that traditional rulers in Tiv be made to take their oath of office by Swem (the Tiv symbol of justice) so that when they renege on their oath, they would immediately bear the consequences (death by swollen stomach, limbs and severe headache). The study concluded that Tiv culture must not be sacrificed on the altar of Christianity by anybody not even the ator (traditional rulers).

Keywords: ator a zan adua, corrosion, Tiv, culture

\section{Introduction}

Before the advent of colonialism on the African political scene, the traditional institution held sway. This implies that the chieftaincy or traditional institution preceded the current political and administrative structure now operational on the African continent. The traditional institution performed various functions for the people ranging from political, religious and socio-cultural. There is no gain stating the obvious fact that the importance of the traditional/chieftaincy institution has ensured that it has survived to this moment across Africa and Nigeria in particular.

Thus, prior to the coming of colonial rule and its dominance of the political scene in Nigeria, various communities had well organised traditional and chieftaincy institutions that were headed by revered Obas, Emirs, Alaafin, Ooni, Eze, Mai, etc. These were responsible for the governance of their various kingdoms, Emirates, empires as the case may be. The traditional/chieftaincy institution then provided and rendered all the services that can be ascribed to any modern government.

However, this well organised and thought of system was outlawed by the colonialist on seizing the reins of power and in its stead introduced a new political order on the African continent and Nigeria in particular. Some of the traditional rulers who were deemed to be "stubborn" following their challenge of the legality of the takeover of their lands by the 
colonialists were banished to distant lands where some of them unfortunately died.

Some of the traditional rulers who suffered this unpleasant fate of deportation include King Jaja of Opobo in the Niger Delta, Abuul Benga, Ugba Gwar and Chief Abagi Kpanju of Ukan, Logo and Shangev-Tiev respectively in Tivland, Chief Abagi Kpanju for instance was not only deposed by the colonialists but executed for the murder of his wife (Wende Akasi 2012:2). To actualize the indirect rule policy, the colonialists where the British ruled by proxy; A house of chiefs was created for the traditional rulers but later was abrogated. Currently, Agaba and Adole (2016:179) posits that neither the 1979 Constitution nor the 1999 Constitution have any role assigned to the traditional institution in Nigeria.

In Tivland, the traditional institution was not originally organised as it is today. Leadership was strictly anchored on gerontocracy where the eldest person presided over the affairs of his family, clan, lineage or kindred as the case may be. This was the practice before the British created the Tor Tiv chieftaincy institution in 1946. By this new development, HRH Orchivirigh Makir Dzakpe emerged the first Tor Tiv in 1947 as the paramount ruler of the Tiv. The traditional institution in Tivland has developed tremendously and several reforms have further expanded the institution to not only harbour the Tor Tiv as paramount ruler; but the Ator ( $1^{\text {st }}$ class chiefs) the Uter (second class chiefs), the Utyo-Mbaiorov-kindred heads (third class chiefs) Mbatarev (clan heads) and the ator a kpande (tax collectors) bridging the rear.

In addition to the above, there are ati ator (honorific title holders) in Tivland who are not traditional rulers in themselves, but act in advisory roles to the paramount ruler. The honorific title holders are well to do individuals in the society; honoured for their achievements in life and contribution to the society and Tiv land in particular.

It is worthy to state at this juncture that a disturbing phenomenon has been unfolding in the Tiv chieftaincy and traditional institution which has to do with the emergence of ator a zan adua (Christian traditional rulers) across Tivland. This cuts across all the strata and segments of the Tiv traditional institution. The truth of the matter is that, as Christian traditional rulers, these emerging set of traditional rulers have tended to project and promote Christian ideas and ideals of this foreign Religion and culture at the expense and detriment of Tiv religion and culture.

While one may hide under the canopy of freedom of association and Religion enshrined in the constitution of Nigeria; what are the Tiv bequeathing their children and generation yet unborn? As custodians of the Religion and culture of the Tiv, should these category of traditional rulers be projecting and promoting Tiv culture or Judeo-European cultures? What are the foreseeable dangers this trend poses if it goes unchecked? These and other related issues would preoccupy the attention of this paper.

\section{Conceptual Framework}

The under-listed words and concepts as discoursed in this paper convey the following ideas.

Culture: The concept culture does not have a univocal meaning. This is because there are different perspectives on culture and so it is difficult to proffer one, universal, blanket 
definition that would cover all aspects in the sense that both the meaning and aim of culture is quite vast and expansive. Thus, in culture one can find, the origin and evolution of all the thoughts, customs, objectives and ethics of a given society.

From the above, standpoint, Deezia (2017:121) citing Edward Burnet Tylor stated that culture is that complex whole which includes knowledge, belief, arts, morals, customs, law and other capabilities which are learned by men as members of society and transmitted from one generation to another.

In other words, culture is a construct used by man in an attempt to analyse and integrate events and ideas in broad spectrum of area of society. It is composed of the total repertoire of human actions which are socially transmitted from generation to generation. Culture is therefore, the totality of learned, socially transmitted customs, knowledge, material objects and behaviour. It includes the ideas, values, customs and artefacts of a group of people (Deezia 2017:121).

Eliot cited by Ndu Johnson (2013:8) looked at culture as Religion and Religion as culture. In this line of thought, Ndu (2013) explained that culture is specifically made i.e man-made and that it is a social heritage, given from one generation to another. He further explained that a person is known by his/her culture because it is his/her way of life and this shapes his/her behaviour.

Furthermore, Malgwa (2011:64) citing Adelakun viewed culture as all things which human beings do but with no biological basis. That is to say, all non-biological behaviours of man are products of culture. Danfulani (2010:2) posits that culture is composed of both ideal and real culture. According to him, Ideal culture refers to social patterns consistent with cultural values and norms; while real culture designates social patterns that actually occur.

On the typology of culture, Malgwa (2011:64) stated that although culture cannot be broken into atoms, its major components can be identified. He thus gave two broad categories of culture to include: material and immaterial culture According to him, material culture refers to all objects, physical traits, instruments and tools which are made and used by a people in various aspects of their community life. These include cutlasses, hoes, brooms, food, pots, clothes, etc. The material culture can thus be said to be the physical, concrete or tangible culture.

On the one hand, immaterial culture is also known as non-material, non-concrete or intangible culture. This is composed of the knowledge, attitudes, values and beliefs, taboos, language, behaviour, ideas which are prevalent aspects consist of the rules, regulations and norms and behaviour (Malgwa 2011:64). From the foregoing, it is pertinent to note that culture is not static, but it grows and is continually in the process of growth and change and it is passed from one generation to the other. In this understanding, Adega (2010:131) observed that some form of culture is changed and new ones acquired. Consequent on the above narrative, it is safe to say that culture has five basic characteristics. These include:

(i) It is common to a group of people who make up a particular society. 
(ii) It is not hereditary but it is learned after birth during the period of socialization.

(iii) It is associated with various symbols such as an image, an object of worship, rituals, texts and artefacts to continue its flow and its dependent on people following the codes of conventions associated with a specific culture.

(iv) It is an amalgamation of social, economic and political features.

(v) It provides a sense of identity to its members, thus, helping them to cope with difficulties during times of stress and lends meaning and continuity. Culture is therefore, never the result of one single person's initiative or endeavour nor can it be said to be the consequence of any particular incident at any particular time.

On the strength of the above analysis, it can be said confidently that the backbone of any society is its culture (Ignou, the Peoples University, nd: 67-69). As stated earlier, culture and Religion are related. This is affirmed by Eliot cited by Ndu (2013:8) who inferred that culture is Religion and Religion is culture. This implies that Religion and culture are interdependent and are inseparable. It is absurd to begin to imagine a culture without Religion or a Religion without culture. Indeed, all religious thoughts owe their origins to the cultures from where they emanate from.

For instance, Christianity is built on the Judeo-European traditions of the Jewish and western European cultures; while Islam is fashioned in the Arabo-Berber traditions of Saudi Arabia. Supporting the notion of the inseparable nature of culture and Religion, Umoren (2018:49) observed that man is generally a religious being, s/he may decide to be formal or informal about this but naturally, s/he is religious by orientation. He maintained that since man understands culture to be the way of life of a people, it would be difficult to separate man's religious nature from his/her culture. Man, as a religious being necessarily brings his/her intrinsic nature into action.

Furthermore, there is no gain arguing the fact that there is a religious aspect in every cultural expression. Towards this, Religion as confirmed by Mbiti (1991:3) is an innate principle in culture.

Tiv Culture: This is the way of life of the Tiv. Tiv culture encompasses the beliefs, practices, arts, culture, traditions, moral laws and values, habits etc. acquired by the Tiv as they journey on earth as a society, that is Tiv society (Ndu Johnson 2013:14) Tiv culture is peculiar to the Tiv and it permeates the society and controls their world view. The interdependence of Religion and culture seems to play much part in Tiv more than other non-African societies.

Gbor (2006:15-16) reiterated the position above by explaining that Tiv culture is Tiv way of life. He posited further that Tiv way of life manifests in all facets of their general life. It is represented by a whole gamut of their cultural items, events and activities of their general life. He concluded by writing that Tiv culture is therefore, a system of ideas, abstracted from the great gamut of events and activities of their general life.

Tiv culture is a systematic body of learned behaviour, transmitted from parents to children, has enabling capabilities for maintaining life. It contains ideas, sentiments, and objects as 
well as social arrangements. According to Gbor (2006:16) those capabilities, systems of ideas and objects manifest in Tiv agricultural system, marriage system, hunting/fishing practices, beliefs system, relation with the cosmos; the political system; the military system; the kinship system and social organisation; the medical system relating to the handling and treatment of the sick etc.

The constellations of all their part together, constitute Tiv culture. Gbor (2006) proffered that it is from the events, objects, and activities, which relate to these spheres of life that the Tiv generate and pass on ideas, through socialization to their future generations. Tiv culture generally has to do with their beliefs, sentiments, feelings, emotions and attitudes.

Traditional Rulers(s): the traditional institution is headed by traditional rulers. Aderayo and Adepoju (2015:90) explained that the traditional rulers are the custodians of culture and traditions who are closely linked with the grassroots and have a better understanding of the problem of the people. The traditional rulers are political leaders who exercise powers at ethnic or sub-ethnic levels in Nigeria.

On his part Akinfewa (2010) stated that a traditional ruler is a person who by virtue of his ancestry, occupies the throne of an area and has been appointed to act according to the customs and traditions of the area and has been in existence before the advent of colonialism in Nigeria. The traditional rulers are part and parcel of the communities and assumed the position being the founders of the communities. Traditional rulers are the leaders of the indigenous political arrangements with proven track records, appointed and installed in line with the provision of native laws and customs. From the above analysis, Sokoh (2018:52) observed that an individual can only become a traditional ruler through inheritance thus, only members of the traditional ruling families can legitimately aspire to become traditional rulers. By its hereditary nature, those who do not belong to that traditional group or do not have a traditional institution cannot become traditional ruler of a given locality or ethnic group even if s/he possess better rulership qualities than members of the "ruling" or royal families; moreover in Nigeria most of the traditional rulers are males hence Nigeria is a patriarchal society.

Ihemeje (2019:4) opined that a traditional ruler is the head of an ethnic group or clan who is the holder of the highest primary executive authority in an indigenous polity, or who has been appointed to such position in accordance with the customs and tradition of the area concerned by instrument or order of the state government, and whose title is recognised as a traditional ruler title holder by the government of the state. By the above understanding; such a person so appointed is conferred with indigenous, cultural, and customary-based authority; and whose reign of a monarchy is the accepted controller of a people in their affairs of life. Traditional rulership institution implies primordial or existing structure designed to rule over indigenous communities/locales with the range of set norms.

Thus, the word traditional used as prefix in this context refers to historic roots of leadership, which legitimizes the execution of power. According to Ihemeje (2019:4) there are many existing forms of traditional leadership. In Europe, the rule of kings and nobles was the dominant governing force for a long time until it was gradually replaced by democratic 
structures. In Africa, Asia and Latin America, traditional authorities are mostly referred to as chiefs and elders.

Navigating back to Nigeria, Ayoo (2008:87) pointed out that, the traditional political systems that were based on chiefs included the Hausa-Fulani emirate system in Northern Nigeria and the Yoruba traditional political system in Western Nigeria. Suffice it to state the obvious fact that determining the exact origin of traditional institution remains elusive but it is certain that most of the nation-state scattered across the then territory now named Nigeria had traditional institution that played a significant role to their growth, influence, development and dominance of other societies.

At the head of every traditional institution sits the traditional ruler who exercises sovereign power over the people. In pre-colonial times, most of the traditional institutions had well-structured system of government that was basically centralized and access to rulership was hereditary. On the relevance and the importance of traditional institution, Omagu (2013:1) argued that despite the assertions that chieftaincy has been overtaken by events, the reality is that the institution has become central to government (in Nigeria) and cannot be discarded.

He maintained that, the challenges of recent times, have raised serious concerns about the importance of the chieftaincy or traditional institution against the backdrop of the institution's ambiguous role in modern times. Regarding the roles, duties and functions of traditional rulers; Aderayo and Adepoju (2015:90) outlined the following:

(1) They are enthroned to preserve the customs, religious traditions and cultures of the people.

(2) They are saddled with the responsibility of managing any conflict(s) or disputes in the communities they govern. This point is also subscribed to by Agaba and Adole (2016:182-184).

(3) They serve as judges and are respected by the people. Their decisions in any matter are deemed final (especially before the advent of modern judicial system).

(4) They are not mere political leaders, but religious leaders. As Kanu (2015:154) rightly projected, it is not surprising therefore, to find that in many parts of Africa, the king, chief or traditional ruler is regarded with religious awe. He forms yet another link in the hierarchy of society which passes from men and women to kings, to ancestors, to gods and up to the supreme God of all.

Kanu (2015) further explained that among the Bantu of South Africa, the King or chief was not just the ruler and law-giver but also the priest and magician. This explains why Mbiti (1969:182) in supporting the assertion above stated that:

Where these rulers are found, they are not sampling political heads: they are the mystical and religious heads, the divine symbol of their people's health and welfare... their office is a link between human race and spiritual government. They are therefore, divine sacral rulers, the show or reflection of God's rule in the universe. 
(5) They play important roles during festivals, initiations coronations and purification rites and being depositories of customs, taboos and theology (Gbenda 1997:41).

(6) Lead during public worship and offering prayer and pouring libation where necessary as the chief priests of their indigenous Religion.

\section{The Evolution of Tiv Traditional Rulership Institution}

Tiv traditional rulership and administration is based on a close kinship which begins with the Ter (the pater familias) extending to the Orvesen (the oldest male member of an extended family) (Tarbo 1980:24). In other words, the Tiv practiced gerontocracy with no central traditional authority, which made the British colonialist refer to them as people of a classless society.

As Rubingh (1969:64) puts it, the Tiv understanding of authority and power arises from a surprising view of leadership which is not amenable to the imposition of either elected or appointed chiefs. Due to the scenario, the Tiv previously did not have a chief who ruled over the ethnic group as a whole. This had to do with the Tiv understanding that mere geographical continuity did not have much to do with political groupings, or alliances. Authority for the Tiv resides intrinsically in the very personality of the leader, he could neither be clothed with it artificially by an appointment.

Adega (2011:70) posited that the practice in which the Tiv did not have a king/chief (traditional ruler) to rule over the whole ethnic group continued for decades until the advent of the British colonial administration in Tivland. Also, the Tiv who had fought in the first and second world wars had interacted with other ethnic nationalities and learned of their traditional institutions which they envied and were desirous of having this non-existing institution introduced in Tivland.

Tarnande (2015:1971) lends credence to the preceding points when he wrote that, those who pioneered the agitation for a traditional/chieftaincy institution for the Tiv included, Orodi Ugba, Akiga Sai and Iyorkyaa Akoo representing the educated Tiv elites. There were also Gyuse Doki, Aemberga Samu, Ula Lisa and Makondo Igbon who were Tiv ex-service men. Also, clan heads such as Jato Aka of Turan (Kwande) and Mkovur Jagera of Ipav (Jemgbagh) were in the vanguard of demanding for a chieftaincy institution for the Tiv.

The British colonial authorities under the leadership of Sir Arthur Richards the then Governor General of Nigeria gave into the demand of the Tiv elites, ex-service men and clan heads. Two reasons accounted for the British accepting to create the Tor Tiv paramount stool for the Tiv:

(i) The British reasoned that without a recognised central authority, administering a classless and segmetery people like the Tiv was herculean.

(ii) The British also realised that the stool when created would help them in administering Tivland through the indirect rule system which was operational and recorded much successes with the emirate system in northern Nigeria and to an extent, the Oba system of the Yoruba (Adega 2011). 
Thus, in 1946, the exalted traditional rulership stool of the Tor Tiv (paramount ruler) was created to oscillate between Ipusu and Ichongo, the two main blocks of the Tiv socio-political organisation. By this development, the occupant of the Tor Tiv stool at once became the principal regonised traditional ruler of all the Tiv. Shading light on this novel development in Tiv society, Igirgi (1993:120) averred that:

The new arrangement though actualised by the colonial government, as a more or less, a validation of channels of previously recognised authority, merely systematized through centralisation. The new system or dispensation afforded the Tiv a unified political front, a clear-cut cultural image and a defined territorial integrity.

Prior to the creation of the Tor Tiv paramount rulership stool in 1946, the Tiv had experimented with a chieftaincy system known as the Tor-Agbande (drum chief). Drum chief, the institution was so known because those appointed were celebrated with drums and other musical instruments. The Tor-Agbande chieftaincy borrowed from the Jukun and occupants coroneted by the $A k u U k a$ of Wukari.

Upon appointment, the Tor-Agbande irrespective of his age would be initiated into the most potent tsav and akombo (witchcraft and mystical powers) of the land by the elders. Downes (1933:30-31) reports that on assumption of office, the Tor -Agbande often became in due course a practitioner of cults and an elder in his turn. Often too, by virtue of influence, he gathered control of all important akombo (rituals/mystical powers) and became a very powerful man.

To further fortify himself, the Tor-Agbande moved a step further than the elders by adding an external dimension when they always visited the Jukun at Wukari or the Abakwariga and Etulo at Katsina- Ala where their supernatural powers were supposedly better enhanced. Outside this arrangement, the Tiv in their gerontocratic system had toyed also with a decentrlised system of village administration where the various elders from the compounds, the Iye igyo council, the ityo council etc had powers to settle disputes and administer justice in the villages. 75 years since its creation (1946-2021) of the Tor Tiv stool, five Tiv sons have ascended the throne in this sequence:

(1) HRH Orchivirigh Makir Dzakpe (Ipusu): 1946-1956.

(2) HRH Orchivirigh Gondo Aluor (Ichongo): 1956-1978

(3) HRH Orchivirigh Dr. James Akperan Orshi (Ipusu): 1978-1990

(4) HRH Orchivirigh Dr. Alfred Akawe Torkula (Ichongo): 1991-2015

(5) HRH Orchivirigh Prof. James Iorzua Ortese Ayatse (Ipusu): 2016- date

The Tor Tiv, the Begha U Tiv (Lion of the Tiv) is the Chairman, Tiv Traditional Council (TTC). The TTC holds its ijir tamen (supreme council) at Gboko, the administrative headquarters of the Tiv, where the matters affecting the socio-religious, political, cultural and economic development of the Tiv are discussed and conflicts resolved (Adega 2011:71). The Tor Tiv doubles as the chairman of the Benue State council of Chiefs - a body of traditional 
rulers who serve the government in advisory capacity and disseminates government policies and programmes to its subjects.

Presently, the TTC is constituted by the Tor Tiv (paramount ruler); the Tor/Ator ( $1^{\text {st }}$ class chiefs, six in number from the intermediate areas), the Ter/Uter ( $2^{\text {nd }}$ class chiefs), the Tyoor/Utyo Mbaiorov ( $3^{\text {rd }}$ class chiefs), the Or tar/Mbatarev (kindred heads) and Tor/Ator a kpandegh (tax collectors). In an expanded capacity, the ati ator (honorific title holders) are also in attendance.

\section{The Emergence of Ator A Zan Adua on the traditional Rulership Scene in Tivland}

According to Karshima (2013: 35/286), Ator (plural) and Tor (singular) refers to kings and king respectively. It is a general but revered name for traditional rulers in Tiv society. The following category of ator are obtainable in Tiv society: The Tor Tiv and Begha U Tiv (paramount ruler); the Tor/Ator (kings) $-1^{\text {st }}$ class chiefs - there are six of these ator representing the six intermediate areas of Tivland: Tor Lobi, Tor Gwer, Tor Jemgbagh, Tor Jechira, Tor Kwande and Tor Sankera.

There are also the Uter (literally fathers) who are $2^{\text {nd }}$ class chiefs cutting across the 14 Tiv speaking local government areas in Benue State alone. Another category of ator are the Tyoor/utyo-mbaiorov (district heads) $-3^{\text {rd }}$ class chiefs; with the or tar (mbatarev) (kindred heads) and Tor kpandelator a kpande (tax collectors bridging the rear (Adega 2011:71). All these categories of ator are members of the Tiv Traditional Council and jirtamen (the supreme council) where matters affecting the wellbeing of Tivland are discussed. It is pertinent to note that the title Tor /Ator does not really apply to the ati ator (honorific title holders) in Tivland; though they may have the prefix chiefs to their names.

Having established the above background, it would now be safe to navigate further by explaining the concept of ator a zan adua. Ator a zanadua in the context of this study literally connotes kings or chiefs who attend adua (church). This in other words, mean Christian traditional rulers. As a matter of fact, most traditional rulers in contemporary Tivland today profess Christianity with some holding high ranking administrative and spiritual positions such as chairmen of church councils, Mbatamen (elders), treasurers, president of laity councils/league as well as the order of knights in various Christian denominations across Tivland.

The ator a zan adua prior to their ascension on the throne of the chieftaincy stool of their areas were educated career civil servants, ambassadors, bankers, politicians, economists, retired police/army officers, legal luminaries, business men, administrators, educationists, academics and retired public servants, medical doctors amongst other occupational engagements. The truth be also told that as a result of these occupational engagements; most of these Tiv left the shores of the villages and Tivland in pursuance of their careers. This singular venture separated them from their people and their cultures for a very long time.

Sources indicate that two related factors accounted for the emergence of the ator a zan adua on the traditional administrative and rulership scene in Tivland. The first factor was the desire of the Tiv to have educated people rule over them. Prior to this desirous need, most of the 
traditional rulers were not schooled in western education, but Tiv indigenous knowledge and education.

The agitators for educated traditional rulers were the ex-service men who had travelled outside the shores of Tivland and Nigeria and had interacted with other nationalities and also seen their traditional rulers who were educated, influential, dignified, respected and honoured. This scenario according to Tarnande (2015:97) made their Tiv ex-service men and educated elites to desire that their traditional rulers earn the same respect. If the traditional rulers were to be accorded this respect and to represent their people anywhere in the world; then they needed to be educated. As Tarnande (2015:105) puts it; there was the need of allowing the voice of the literate young Tiv to be heard.

The second factor responsible for the emergence of the ator a zan adua on the traditional rulership scene in Tivland had to do with the allure of the office of the traditional institution which attracted several people to vie for their revered positions. This consequently introduced stiff competition in chieftaincy issues and created a rift between contestants who became sworn enemies of each other.

The allure of the office of the ator came with the various reforms carried out over time by the Tiv area traditional council and the Benue State government which accorded several privileges, respect, prestige and financial emoluments amongst other juicy entitlements. All these factors created a heavy grid lock on the traffic lane of contestants into traditional rulership positions in Tivland.

It is to be recalled that in the not too distant past, the chieftaincy and traditional rulership position in Tivland was the exclusive reserve of Tiv traditionalists and perhaps nominal Christians plying both trades of tradition and Christianity. In other words, real Christians were dissuaded from taking up traditional rulership or even chieftaincy titles. This scenario played out also in other ethnic nationalities in Africa. Omagu (2013:2) confirmed this much when he wrote that the reason why Christians declined traditional rulership position was probably because ascending any chieftaincy position involved an incredible number of elaborate rituals, and regulated all traditional religious ceremonies as well as sacrifice (human/material).

Since Christian norms and values opposed these traditional rituals/sacrifice performances, most "practicing" Christians could not take up these positions even if they desired to do so or even if it were the turn of their clans or kindred to put forward a candidate and they were the most qualified. All these cautions it would now appear have been thrown to the dogs. Another related issue which hindered Christians from vying for chieftaincy and traditional rulership positions in Tivland had to do with tsav (witchcraft).

Tsav is a major component of Tiv religion and it lends credence to the Tiv worldview explaining phenomenon. Gbenda (1997:21) was absolutely right when he posited that: Among the Tiv, the invisible interaction plays a preponderant role as issues of the day (physical) are usually decided in the night (spiritual - metaphysical). Thus, the elders usually commune and interact with invisible beings to arrive at decisions on matters affecting the 
people. Therefore, a traditional ruler in Tivland is regarded as a "ghost - ruler" if he fails to acknowledge and interact spiritually with other traditionalists using sacred cult objects like imborivungu (owl pipe), pôor (ancestral relics) and Ibiamegh (prosperity cult) (Adega 2018:98-102); which bring wealth and fame and make a man of substance respectable. As a result of all these, Christian ministers/clergy had their axes of ex-communication dangling on the necks/heads of erring members and true to type most were put in check.

The first of the ator a zan adua to emerge on the traditional rulership (stool) scene in Tivland was HRH Orchivirigh Dr. James Akperan Orshi, a legal luminary of the Nongo U KristuU Iser U Sha Tar (NKST) - Tor Tiv III in 1979. He was followed by HRH Orchivirigh Dr Alfred Akawe Torkula 1991 and HRH Orchivirigh Prof. James Iorzua Ortese Ayatse 2016. The ator a zan adua are similarly scattered across the other categories/levels of the chieftaincy/traditional rulership institution in Tivland.

\section{Ator a zan adua and the Corrosion of Tiv Culture in the $21^{\text {st }}$ Century}

The Department of Religion and Cultural Studies at the Benue State University, Makurdi organises an annual field work/excursion for 300 level students in the course, REL 308: Traditional Religions of the Benue People. One week is spent gathering information from the field from practitioners of the Indigenous/Traditional religious beliefs of the people of Benue State. Tivland has also featured prominently in the places visited during these field works which is anchored by staff in the Department specialising in African Religion.

The leading researcher joined the services of the University and the Department in 2007. From this period onwards the 14 Tiv speaking Local Government Areas in Benue State have been covered by the team. However, it has come to the observation and dismay of the researchers that in the host communities, some of the ator (chiefs) across Tivland have lost touch with Tiv culture and are gradually but systematically entrenching foreign cultures Christianity on the Tiv.

Most of this ator who profess the Christian faith had in pursuance of their careers left Tivland for long and Tivland and Tiv culture had equally left them. They therefore do not have a grasp of Tiv culture and have tended to use foreign cultures ad yardstick for governing their people. And as the $21^{\text {st }}$ century edges deeper, Tiv culture is gradually wearing out and new cultures are being imbibed. It is not an exaggeration to state that when two cultures interact, the superior culture swallows up the lower/inferior culture. This is the dilemma that Tiv culture faces today coupled with the Hausa/Fulani influence. It would appear that the ator $a$ zan adua are becoming the number one problem of Tiv culture. The ator a zan adua are indeed, the tsunami of Tiv culture instigating its systematic corrosion, erosion and decline.

To begin with, during the field works/excursions; personal interviews with these traditional rulers indicated that they feigned an understanding of Tiv culture and would to the utter dismay of the researchers, make references to the Bible when commenting on Tiv culture. Tiv culture cannot be deliberately subsumed into other cultures for whatever reason in the sense that a people without a culture have no identity. What legacy are these ator leaving behind? What are they bequeathing to the generations of Tiv yet unborn? Christian norms and values? 
Similarly, because of their faith, most of the ator a zan adua today take the oath of office by swearing to the Bible with the exception of Tor Tiv IV, Dr. Alfred Akawe Torkula who took his oath of office by Swem - the Tiv potent symbol of justice (Shishima 2000:4). The question is to who do these traditional rulers owe allegiance, the Tiv culture represented by Swem or Christianity represented by the Bible? The traditional rulers are supposed to be the custodians of the people's culture not foreign cultures. They by virtue of the sacred and revered positions which they occupy are the chief priests of the indigenous religions of their people. They can pour libations and offer sacrifices on behalf of the people where the need arises.

Relatedly, in the recent times, traditional rulers in Tivland have been in the forefront of calling out their subjects for days of prayers, fasting and meditation in the Bible in times of trouble and need. Where is the place of Swem to which the Tiv embarked on annual pilgrimage to and where most of the problems affecting Tivland; socio-economic, political, cultural, health/infertility were resolved and tarTiv regained its potency and infertility. Moti and Wegh (2001:60) reported that Swem as a place is very significant in Tiv religious thoughts because the head of Takuruku, the progenitor of the Tiv ethnic group had ashes of his skull scattered at Swem. It was also at Swem that the Tiv became aware of their Tivness.

Where are the Aondo u Abaverjua, Aondo u Iyol Koo, Aondo u Agbilekper etc? Are the Tiv Gods on retreat? Why are the Tiv unable to call on them today? Are the Tiv of today fundamentally different from the Tiv of yesterday? What really is the problem of the Tiv today that even their culture which is their only form of identity being sacrificed on the altar of Christianity by the traditional rulers/ator? Other areas which the ator a zan adua have aided and abated in the corrosion of Tiv culture include: reading the Bible and preaching at public functions even where the clergy are present. The Bible does not contain Tiv culture which supposedly they are the custodians. On their selection and installation, the ator a zan adua hurriedly move to organise thanksgiving masses/services in churches where they sit in the front pews.

Not only that, the ator a zan adua have tended to discourage Tiv cultural practices including $k u$ oron (inquest) ishor $i$ kpehen (divination), tsav (witchcraft), akombo (rituals), medicine and healing. They openly tell their subjects that these cultural practices are evil which is not completely true. As Adega (2018:222) pointed out, ichin tan (warning) at inquests against the frequency of deaths are no longer taken serious and perpetrators of evil in the society use the lapse to cause harm to others claiming that Christians are soft targets whose deaths will not be questioned/investigated - mbakristu doo wuan.

The ator azan adua are thus deeply contributing to the "churchmentation" and Christianization of the Tiv culture; thereby leading to its complete erosion. Most Tiv are of the view that these and other related issues are responsible for why the traditional rulers lack authority and when they speak, they are not taken seriously or respected. They have lost touch with both their subjects and their culture.

6. Ator aa zaan adua kpa anaan aerenakaa aa Tiv ichivir (Christian traditional rulers should respect Tiv culture): Towards the Sustenance of Tiv Culture 
The paper has examined the issue of chieftaincy and traditional rulership institution among the Tiv. It established that the Tiv initially practiced leadership by gerontocracy in which the most elderly person presided over matters in the various clans in the villages. Later, the Tor Agbande (drum chiefs) came on board as the Tiv started agitating for a single person to rule over the whole ethnic group. This was climaxed with the creation of the Tor Tiv paramount ruler stool for the Tiv in 1946.

Along the line, the Tiv also saw the need and desire to have educated people rule over them. This led to the emergence of the ator a zan adua - who are mostly educated Tiv elites who profess the Christian faith. However, their emergence on the traditional rulership scene in Tivland has come with some challenges to Tiv culture as it is gradually being supplanted with Christian values and norms. In order to protect Tiv culture from completely corroding so as to preserve it for generations yet unborn of the Tiv; the study offer the following as way forward:

(i) The Tiv are called upon to hold onto their culture wherever they find themselves. A situation where Tiv sons and daughters born in Lagos, Jos or Kaduna cannot speak Tiv fluently is not encouraging. The Hausa speak Hausa language even in developed places like America, Britain; Germany, France and China and have airtime on international Radio channels. Tiv parents must value Tiv culture and bequeath same to their children.

(ii) All traditional rulers in Tivland should and as a matter of fact, must show respect and honour to Tiv culture. They should be seen to be doing so diligently as the custodians of the peoples' Religion, cultural norms and values. No foreign culture(s) should be prized and valued more than the culture which they took an oath to defend, protect and preserve. Tiv culture should not be taken as an extension of Christianity.

(iii) The Tiv Traditional Council (TTC) should ensure; by making it a policy that all traditional rulers in Tivland irrespective of their religious creed and affiliation take their oath of office by Swem. Those who object to this arrangement should be asked to give way to willing aspirants who would give the assurance to protect a culture they represent.

(iv) Also, in the selection of Traditional rulers in Tivland; the king makers should ensure that only the most qualified and knowledgeable in Tiv culture are selected. As it is, there are noticeable flaws in the selection process. Ihagh (2020:26) alluded much to this when he opined that, some of the traditional rulers were not appointed following due process. Most Tiv refer to them as ator a gomenti - government traditional rulers acting out government scripts and as such not taken seriously and their words are meaningless and weightless before the people. This also accounts for the faulty decisions which these traditional rulers take thus exacerbating communal unrest and skirmishes in Tivland.

(v) Politicians should desist from bringing to bear politics in matters of Tiv Religion and culture which is outside the purview of their domain. Politicians in contemporary Tiv society use their wealth and affluence to hijack and influence the selection of some individuals wrongly into traditional leadership positions. These become stooges exploited by these politicians, messing up everything. Some of these "stooge" traditional rulers in a bid to redeem 
their image try feebly to resist being used but are quickly reminded of how they ascended the throne and they submit; while those who prove to be too forward are suspended and de-beaded.

(vi) The Tiv Traditional Council (TTC) must make it a policy for all traditional rulers in Tivland to be domiciled with their subjects in their domains. Many a traditional ruler in Tivland stay away from their domains and pay occasional visits when it becomes necessary. In so doing, they do not govern their people properly, neither are they in position to know their challenges. Thus, if an individual is Tor in Sankera or Katsina-Ala; he should stay with his subjects in those areas rather than making Makurdi or Abuja his safe haven. Traditional rulers in Tivland should not rule their people by proxy or from the diaspora; Tivland is too good and beautiful for that.

(vii)In addition to the above, the Hausa have an adage which says "in gemun makopchinka ya kama wuta sai ka shafa wa naka ruwa", literally meaning when your neighbour's beards catches fire, you rub water on yours. This is to prevent the fire from spreading to yours and causing you damage. In other words, the need for prevention being better than cure. This call is made with reference to the incidence involving the ransacking of the Oba of Lagos and Seun of Osogbo palaces by the ENDSARS protesters on the $21^{\text {st }}$ October, 2020 following the Lekki toll gate Shootings and killing of protesters in Lagos.

What is being suggested here is that the traditional institution in Tivland should take precaution from what happened in Lagos and Osogbo. Because if the Tiv become disenchanted with their leadership ineptitude characterised by the entrenchment of foreign cultures, they may be forced to revolt against the traditional institution/rulers in protest. In order words the Tiv would be saying "enough is enough" to these Christian traditional rulers.

Ordinarily, the traditional institution is revered and respected and people even seek refuge in palaces and they are protected. So what went wrong that the subjects turned against their traditional rulers who are closest to them? The carting away of the Oba of Lagos' insignia/staff of office is even more appalling. In the strictest of sense, no subject dares to remove the king's staff of office. A traditional ruler's staff of office would not even move from where it is placed or kept by palace officials because it is fortified spiritually.

Such objects can only be so easily moved if they are in danger of destruction such as an inferno. In such situations, a woman can even move it without much ado. Unless of course, also in situations where the ancestors and the Gods have departed from a traditional ruler for his misdeeds. Traditional rulers in Tivland should be weary of the development in Lagos and Osogbo. It is a possibility that there was disconnect between the affected thrones and the subjects.

\section{Conclusion}

In conclusion, it is apt to note that the institution of chieftaincy is one of the most enduring traditional institutions of Africa despite the various challenges it has faced over time. It has indeed, showed remarkable resilience from colonial through the post-colonial times. The traditional rulers performed executive, legislative, judicial, military, economic and religious roles (Omagu 2013). Despite its declining nature in contemporary times, it has remained relevant and cannot be easily discarded. 
The Tiv initially did not operate an organized chieftaincy or traditional rulership institution. They rather operated a gerontocratic system in which the most elderly person from each compound, clan, kindred etc presided over the affairs and matters addressed. The desire of the Tiv to have a unified ruler with executive powers ushered in the Tor Agbande (drum chief) borrowed from the Jukun of Wukari. The ator agbande (plural) also were coroneted by the Aku Uka of Wukari. This trend continued until the Tor Tiv stool was assented to and created for the Tiv by the British colonialists in 1946 to oscillate between the two-ruling housing of Ipusu and Ichongo.

As could be expected, the British did that to facilitate the smooth operation of indirect rule in Tivland. Something which had failed woefully among the Tiv. As major re-organisations on the chieftaincy institution in Tivland continued; there emerged on the traditional rulership scene of the Tiv the ator a zan adua (Christian traditional rulers) who are also well educated. They had served as career civil servants, retired army/police officers, etc before ascending the throne. However, rather than their reigns bringing abundant blessings, the Tiv are witnessing a corrosion of their culture in the hands of these traditional rulers who are entrenching Christian values and norms on the Tiv. This means these traditional rulers are caught in the dilemma of two systems - Tiv cultural values which they are supposed to represent and protect and Christianity a faith which they profess.

This clearly shows that the ator a zan adua have comprehensively failed in rendering to Caesar what is Caesar's and to God what is God's (cf. Matt. 22:20-21). They are therefore, doing a dis-service to the Tiv and their culture which risks being blotted out in the very near future if corrective measures are not adopted to forestall further corrosion of Tiv culture.

Traditional rulers in Tivland should note that other ethnic nationalities like the Igbo, Yoruba, Bini, Edo, Ibibio and their backyard neighbours, the Idoma and Igede have not sold their cultures on the alters of Christianity. The Ochi'Idoma as educated as he is never speaks English to visiting personalities to his palace. The Ooni of Ife is seen performing rituals and sacrifices for his subjects; just as does the Oba of Benin. The Hausa, Igbo and Yoruba openly project their cultures in Kannywood and Nollywood films. Why is the case of the Tiv different?

The study has proffered several suggestions towards the sustenance of Tiv culture including ator (traditional rulers) being sworn to office by Swem and for the Tiv to value their culture, more than foreign cultures even if such cultures are more sophisticated. Traditional rulers in Tivland should not only project the Tiv culture of their choice like the designing and adorning in Tiv cultural attires like the "anger",Zege mule or Ivav tyo. Tiv culture is more than mere expression in clothing and beads. Tiv culture represents the totality of the Tiv person, it is his/her identity showing who he/she is - Tivness. Therefore, concluding this piece in the words of Ihagh (2020:26), will be appropriate as he adviced the Tiv to shun petty nepotism based on kinship and family. The Tiv are to look for development minded individuals when they seek to select people into public offices such as chieftaincy positions. Tiv cultural heritage must not be sacrificed on the altar of Christianity, the Tiv have suffered long enough in Nigeria, and their culture must be preserved for the generation of Tiv yet un-born. Enough 
should certainly enough; enough of the entrenchment of foreign cultural values on Tiv culture by traditional rulers in Tivland. Tiv Religion and cultural values must no play second fiddle to any one culture in the world no matter how sophisticated that culture may be. The Tiv must not lose their means of identity.

\section{References}

Adega, A. P. (2010). The Impact of Globalization on African Couture: Insights from the Tiv of Nigeria. Bulleting of African Religion and Culture (BARC), 5(1). Print.

Adega, A. P. (2011). The Tor Tiv Titular Institution and the Problem of Authority. African Journal of Cultural, Religious, Educational and Environmental Sustainability (AJCREES), 1(1). Lagos: Destiny Ventures. Print.

Adega, A. P. (2018). The Ritual Symbolism of Death, Burial and Ku Oron (inquest) in Tiv Religious Culture. Enugu: Hossannah Books. Print.

Aderayo, A. A., \& Adepoju, A. (2015). Traditional Rulers as Messianic Agents in Conflict Management in Yoruba Land. African Journal of Local Societies Initiatives (LOSI), 4(2). Print.

Agaba, J. E., \& Adole, J. O. (2016). The Role of Traditional Rulers in the Sustenance of Peace and Stability under the Democratic Government in Benue State from 1999-2011. African Journal of Local Societies Initiative (LOSI), 5(1). Print.

Agir, L. (2020). CP Iorbee Ihagh: Can he forge a new Tiv Unity? The Catholic Star Newspaper, October first edition. Print.

Ayoo, F. A. (2008). Simplified Government for Senior Secondary and Tertiary Institutions. Katsina-Ala: Climax Graphics and Publishers. Print.

Danfulani, U. H. (2010). Religion, Culture and Nation Building in an Age of Globalization: The Way Forward for the Tourism Industry on the Jos Plateau. Bulletin of African Religion and Culture (BARC), 5(1). Jos: Global Emancipation Multi-Services.

Deezia, B. S. (2017). Westernization: The Opening of the Pandora's Box on African Cultural Value System. In Religion in Historical Perspective: Essays in Honour of Professor E.S. Akama. Port Harcourt: Chadik Press. Print.

Downes, R. M. (1933). The Tiv Tribe. Kaduna: Government Printer. Print.

Gbor, J. W. T. (2006). The Concept of Culture and Tiv Cultural Values. Jos: Seeye Prints. Print.

Igirgi, A. D. (1993). External Influences on Tiv Culture: The Tiv in Contemporary Nigeria. Zaria: Writers Organization. Print.

Ihemeje, G. C. (2019). Traditional Rulers, Electoral Process and Nigeria's Fourth Republic: Exploring Relevance. Advances in Politics and Economic, 21(1). Print. https://doi.org/10.22158/ape.v2n1p1 
Kanu, I. A. (2015). A Hermeneutic Approach to African Traditional Religion, Theology and Philosophy. Jos: Augustinian Publications.

Karshima, D. T. (2013). New Tiv-English Dictionary. Makurdi: Ter Books. Print.

Malgwa, J. B. (2011). Traditional Moral Values: An Instrument for Cultural Identity. African Journal of Cultural, Religious, Educational and Environmental Sustainability (AJCREES), 1(1). Lagos: Destiny Ventures.

Mbiti, J. S. (1969). African Religions and Philosophy. London: Heinemann. Print.

Mbiti, J. S. (1991). Introduction to African Religion. London: Heinemann. Print.

Moti, J. S., \& Shagbaor, F. W. (2001). An Encounter Between Tiv Religion and Christianity. Enugu: Snaap Press. Print.

Ndu, J. I. (2013). African Perspective to Sociology of Religion. Port Harcourt: De-Caritas Publishers.

Omagu, D. O. (2013). African Culture and Tradition of the Crossroad: The Institution of Chieftaincy and the Paradox of Modernity in Bekwarra. Canadian Social Science, 9(6). Print.

Rubingh, E. (1969). Sons of Tiv: A Study in the Rise of the Church Among the Tiv of Central Nigeria. Grand Rapids, Michigan: Baker Book House. Print.

Shishima, S. D. (2000). Swem: A Tiv Symbol of Justice. Swem: A Journal of Religion and Philosophy. Print.

Sokoh, G. C. (2018). A Historical Analysis of the Changing Role of Traditional Rulers in Governance in Nigeria. IOSR Journal of Humanities and Social Sciences (IOSR-JHSS), 23(1), ver.2. Print.

Tarbo, N. N. (1980). Marriage among the Tiv. A Tesina submitted in partial fulfillment of the Requirements for Licentiate in Canon Law. Rome. Print.

Tarnande, T. (2015). Ya na Angbian: The Principle, Practice and Relevance in Contemporary Tiv Society. Makurdi: Selfers Academic Press.

Umoren, G. E. (2018). Harnessing and Application of Religious Culture for Sustainable Development in Nigeria. Journal of University Scholars in Religions (JUSREL), 8(1). Print.

Wende, A. (2010). Utor mba ken tar Tiv. Makurdi: Modern Authors Network. Print.

Wende, A. (2012). Statistics of Past Kings in Tiv Kingdom. Vandeikya: Educational Resource and Documentation. Print. 


\section{Copyrights}

Copyright for this article is retained by the author(s), with first publication rights granted to the journal.

This is an open-access article distributed under the terms and conditions of the Creative Commons Attribution license (http://creativecommons.org/licenses/by/4.0/) 